\title{
Thermal Analysis of Dental Impression Waxes
}

\author{
John M. Powers and Robert G. Craig \\ School of Dentistry, The University of Michigan, Ann Arbor, Michigan 48109, USA
}

Ten dental impression waxes were characterized by penetration and differential thermal analysis. Penetration and initial transition temperatures were directly correlated. Penetration at $37 \mathrm{C}$ ranged from 2.5 to $22 \%$ for bite waxes and was $100 \%$ for corrective zevaxes. Distortion of an impression wax may occur upon removal from the mouth.

\section{J Dent Res 57(1) : 37-41 January 1978.}

Differential thermal analysis (DTA) of commercial and dental inlay waxes has established the presence of solid-solid and melting transitions. ${ }^{1}$ The phase changes associated with these transition temperatures were shown to influence the mechanical behavior of the wax. ${ }^{2,3}$ Commercial and dental waxes that were resistant to flow at mouth temperature had no solid-solid transitions below $37 \mathrm{G}$ or had highmelting ester components or both. The purpose of this study was to characterize the thermal and mechanical behavior of dental impression waxes, since these waxes are formulated to exhibit high flow and ductility. ${ }^{4}$

\section{Materials and Methods}

Commercial impression waxes, as received from the manufacturer (Table 1), were subjected to thermomechanical analysis (TMA) in the penetration mode and to DTA. Waxes $\mathrm{D}, \mathrm{E}$, and $\mathrm{I}$ are corrective waxes that record tissues in a functional state. Waxes $F, G, H$, and $J$ are bite waxes. Waxes $A, B$, and $C$ are compounded in varying consistencies representing soft, medium, and hard materials and are

Received for publication December 13, 1976.

Accepted for publication May 4, 1977.

This investigation was presented at the Annual Meeting of the American Association for Dental Research in Las Vegas, Nevada, June 1977.

* DuPont 941 Thermomechanical Analyzer, E. I. du Pont de Nemours \& Co., Inc., Instrument Products Division, Wilmington, De.

t The magnitude for this stress is equal to that specified in American Dental Association Specification No. 4 for Dental Inlay Casting Wax for the flow test.5

* Du Pont 900 Differential Thermal Analyzer, E. I. du Pont de Nemours \& Co., Instrument Products Division, Wilmington, De. used to support D which actually contacts and registers the detail of the soft tissues. Cylindrical wafers $(6.0 \mathrm{~mm}$ in diameter and $1.0 \mathrm{~mm}$ in height) of a wax were made in a stainless steel die. TMA* was carried out on three specimens each for stresses of 14.9 and $250 \dagger \mathrm{kPa}(1.52$ and $25.5 \mathrm{~g} / \mathrm{m}^{2}$, respectively) from $25 \mathrm{C}$ to the temperature at which maximum $(100 \%)$ penetration occurred for the various waxes. The quartz penetration probe has a diameter of 0.92 $\mathrm{mm}$ and a length of $0.72 \mathrm{~mm}$; thus $100 \%$ penetration refers to a vertical displacement of 0.72 $\mathrm{mm}$. The calibration procedure has been described elsewhere. ${ }^{2}$ The analysis was conducted in air, and a linear heating rate of $5 \mathrm{C}$ per minute was used. All TMA curves began $25 \mathrm{C}$ with zero percent penetration. Temperatures at which 10,50 , and $90 \%$ penetration occurred and the percent penetration that occurred at $37 \mathrm{C}$ were recorded. DTA** was carried out on three specimens from $25 \mathrm{C}$ to $100 \mathrm{C}$ in air with a heating rate of $20 \mathrm{C}$ per minute as described elsewhere. ${ }^{1}$

Data were analyzed statistically by analysis of variance ${ }^{6}$ and means compared by Scheffe intervals ${ }^{7}$ computed from the analysis at the $95 \%$ level of confidence.

\section{Results}

DTA thermograms are shown in Figure 1 for the impression waxes in order of increasing temperature of the initial endothermic transition. The waxes $E, D, I, C$, and $H$ had initial transition temperatures below $37 \mathrm{C}$, whereas the waxes $B, G, A, F$, and $J$ had initial transition temperatures above $37 \mathrm{C}$. The peak temperatures reported for each curve were corrected for nonlinear response of the DTA thermocouples, whereas the curves themselves were not corrected. An analysis of variance of the initial transition temperatures indicated there were significant differences among the means $\left(F_{.95: 9.20}=1420\right.$ ). A comparison of means by a Scheffe interval of $1.5 \mathrm{C}$ indicated there were no significant differences among the means of $\mathrm{E}, \mathrm{D}$, and $\mathrm{I}$, nor between $\mathrm{H}$ and $\mathrm{B}$. 
TABLE 1

Code, Batch Number and Manufacturer of Commercial IMPRESSION WAXES

\begin{tabular}{|c|c|c|c|}
\hline Code & Product & Batch Number & Manufacturer \\
\hline A & $\begin{array}{l}\text { Kerr Korecta-Wax } \\
\text { Extra Hard No. } 1\end{array}$ & 1711658 & $\begin{array}{l}\text { Kerr Manufacturing Co. } \\
\text { Div. of Sybron Corp. } \\
\text { Romulus, Mi } 48174\end{array}$ \\
\hline B & $\begin{array}{l}\text { Kerr Korecta-Wax } \\
\text { Hard No. } 2\end{array}$ & $0784 \mathrm{M} 569$ & Kerr Manufacturing Co. \\
\hline $\mathrm{C}$ & $\begin{array}{l}\text { Kerr Korecta-Wax } \\
\text { Hard No. } 3\end{array}$ & $0432 \mathrm{~B} 210$ & Kerr Manufacturing Co. \\
\hline D & $\begin{array}{l}\text { Kerr Korecta-Wax } \\
\text { Extra-Soft No. } 4\end{array}$ & $0703 W 085$ & Kerr Manufacturing Co. \\
\hline $\mathrm{E}$ & $\begin{array}{l}\text { Kerr Impression } \\
\text { Wax Sticks }\end{array}$ & $0801 W 123$ & Kerr Manufacturing Co. \\
\hline $\mathrm{F}$ & $\begin{array}{l}\text { S.S. White Yellow } \\
\text { Bite and Impression } \\
\text { Wax }\end{array}$ & 7686912 & $\begin{array}{l}\text { S. S. White Division } \\
\text { Pennwalt Corp. } \\
\text { Philadelphia, Pa } 19102\end{array}$ \\
\hline G & $\begin{array}{l}\text { Hygienic Yellow } \\
\text { Bite Wax }\end{array}$ & 07281 & $\begin{array}{l}\text { Hygienic Dental Mfg. Co. } \\
\text { Akron, Oh } 44310\end{array}$ \\
\hline $\mathrm{H}$ & $\begin{array}{l}\text { J. F. Jelenko Hi Fi } \\
\text { Functional Bite } \\
\text { Material }\end{array}$ & $\ldots \ldots \ldots$ & $\begin{array}{l}\text { J. F. Jelenko \& Co. } \\
\text { Pennwalt Corp. } \\
\text { New Rochelle, NY } 10801\end{array}$ \\
\hline I & Aluwax & .............. & $\begin{array}{l}\text { Aluwax Dental Products Co. } \\
\text { Grand Rapids, Mi } 49508\end{array}$ \\
\hline $\mathrm{J}$ & Kerr KWIK-WAX & $1204 Y 513$ & Kerr Manufacturing Co. \\
\hline
\end{tabular}

Temperatures (corrected) at which penetrations of 10,50 , and $90 \%$ occurred are listed in Table 2 for the waxes at stresses of 14.9 and $250 \mathrm{kPa}$. The waxes are ranked in order of increasing temperature corresponding to $90 \%$ penetration at a stress of $250 \mathrm{kPa}$. An analysis of variance of the temperatures corresponding to $90 \%$ penetration at $250 \mathrm{kPa}$ indicated there were significant differences among the means $\left(F_{95: 9.20}=508\right)$. A comparison of means by a Scheffe interval of $2.1 \mathrm{C}$ indicated there were no significant differences between the means of $\mathrm{E}$ and $\mathrm{D}, \mathrm{C}$ and $\mathrm{I}, \mathrm{I}$ and $\mathrm{B}, \mathrm{H}$ and $\mathrm{G}$, nor $\mathrm{A}$ and $\mathrm{J}$, as illustrated by underscoring in Table 2 .

Penetration thormograms are superimposed on DTA curves in Figure 1 for the waxes. The penetration curves at the higher stress (curves 2, \# $250 \mathrm{kPa}$ ) appeared to be related to the initial endothermic transitions for the waxes tested; therefore, a plot of the mean value of the temperature $\left(T_{p}\right)$ at which $90 \%$ penetration occurred at $250 \mathrm{kPa}$ versus the mean value of the initial transition temperature $\left(T_{i}\right)$ was made (Fig 2). The correlation coefficient $(r)$ for waxes $\mathrm{A}$ to $\mathrm{J}$ was computed ${ }^{6}$ to be 0.919 . The critical value of $r$ above which the hypothesis of independence of $T_{p}$ and $T_{i}$ could be rejected was 0.632 at the $95 \%$ level of confidence.

The penetration curves at the Iower stress level (curve 1, 14.9 $\mathrm{kPa}$ ) were of two types as exemplified by waxes $\mathrm{A}$ and $\mathrm{D}$ in Figure 1. Waxes $F, G, H$, and $I$ had penetration curves similar to wax A for which some initial penetration occurred at the initial transition, but for which the major penetration was related to the second transition. Waxes $\mathrm{B}, \mathrm{C}, \mathrm{F}$, and $\mathrm{J}$ had penetration curves similar to wax $\mathrm{D}$ for which the major penetration at $14.9 \mathrm{kPa}$ occurred over a temperature ran're nearer to the onset of the second transition than to the peak temperature as for wax A.

By inspection of Figure 1 and Table 2, it was observed that four waxes ( $C, D, E$, and $\mathrm{I}$ ) had values of temperature at which $90 \%$ penetration occurred at $250 \mathrm{kPa}$ that were below $37 \mathrm{C}$. The mean values with standard deviations in parentheses of percent penetration that occurred at $37 \mathrm{C}$ and $250 \mathrm{kPa}$ in order of decreasing penetration were determined from the penetration curves to be: E, D, C, and I, 100; B, $79.3(3.5) ; \mathrm{H}, 22(7) ; \mathrm{G}, 8.0(0.7) ; \mathrm{J}, 5(1)$; A, $4.4(2.3)$; and $\mathrm{F}, 2.5(0.2)$. 


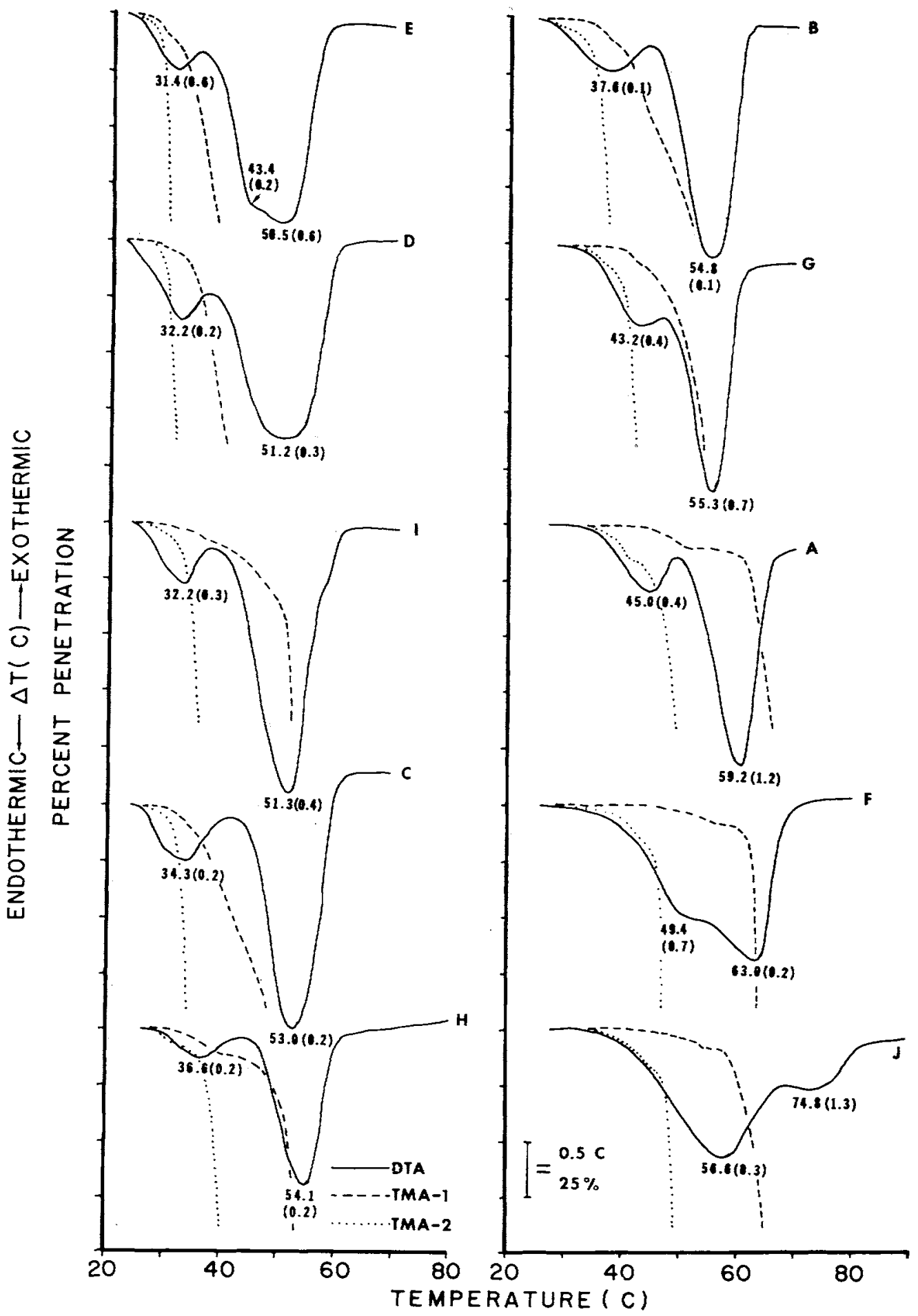

Frg 1.-DTA and penetration (TMA) curves of ten dental impression waxes. Stresses for TMA-1 and 2 are 14.9 and $250 \mathrm{kPa}$, respec-

tively. Mean values for the peak transition temperatures (corrected) from DTA are indicated with standard deviations in parentheses. 
TABLE 2

Penetration Temperatures (Corrected) of Ten Dental Impression Waxes at Two Stress Levels

\begin{tabular}{|c|c|c|c|c|c|c|c|c|c|c|c|}
\hline $\begin{array}{l}\text { Stress, } \\
\text { kPa }\end{array}$ & $\begin{array}{l}\text { Penetration } \\
\%\end{array}$ & \multicolumn{10}{|c|}{ Penetration Temperatures of Waxes, $\mathrm{C}$} \\
\hline \multirow[t]{10}{*}{14.9} & 10 & $\begin{array}{l}30.2^{*} \\
(0.2)\end{array}$ & $\begin{array}{l}33.1 \\
0.7\}\end{array}$ & $\begin{array}{l}34.0 \\
(0.7)\end{array}$ & $\begin{array}{l}37.9 \\
(1.4)\end{array}$ & $\begin{array}{l}38.1 \\
1.3\end{array}$ & $\begin{array}{l}40.7 \\
(2.5)\end{array}$ & $\begin{array}{l}44.2 \\
(0.8)\end{array}$ & $\begin{array}{l}59.2 \\
(1.2)\end{array}$ & $\begin{array}{l}53.9 \\
(3.7)\end{array}$ & $\begin{array}{l}56.5 \\
1.0)\end{array}$ \\
\hline & 50 & 36.0 & 37.6 & 42.0 & 40.5 & 46.0 & 52.6 & 51.5 & 62.2 & 63.8 & 62.3 \\
\hline & & $(0.4)$ & $(0.0)$ & $(0.6)$ & $(0.6)$ & (1.0) & $(1.8)$ & $(0.1)$ & $(0.1)$ & $(0.8)$ & $(0.6)$ \\
\hline & 90 & $\begin{array}{l}38.7 \\
(0.6)\end{array}$ & $\begin{array}{l}40.0 \\
(0.1)\end{array}$ & $\begin{array}{l}47.7 \\
(0.3)\end{array}$ & $\begin{array}{l}41.8 \\
(0.3)\end{array}$ & $\begin{array}{l}51.3 \\
(0.4)\end{array}$ & $\begin{array}{l}54.6 \\
(4.5)\end{array}$ & $\begin{array}{l}53.2 \\
(0.3)\end{array}$ & $\begin{array}{l}62.4 \\
(0.0)\end{array}$ & 66.2 & $\begin{array}{l}64.3 \\
(0.4)\end{array}$ \\
\hline & 10 & 27.8 & 29.0 & 31.4 & 30.5 & 33.3 & 34.0 & 37.9 & 42.9 & $41.0^{\prime}$ & 41.1 \\
\hline & & $(0.2)$ & $(0.2)$ & $(0.2)$ & (2.1) & $(0.2)$ & $(1.2)$ & $(0.2)$ & (1.5) & (3.5) & (3.5) \\
\hline & 50 & 29.3 & 30.4 & 33.3 & 34.2 & 36.2 & 38.7 & 40.9 & 46.6 & 47.9 & 48.8 \\
\hline & & $(0.2)$ & $(0.2)$ & $(0.1)$ & $(0.2)$ & $(0.1)$ & $(0.3)$ & $(0.4)$ & $(0.3)$ & (1.3) & $(0.2)$ \\
\hline & $90 \dagger$ & 29.9 & 31.2 & 34.1 & 35.5 & 37.2 & 40.0 & 41.6 & 47.0 & 49.3 & 49.4 \\
\hline & & $(0.2)$ & $(0.2)$ & $(0.1)$ & $(0.2)$ & $(0.2)$ & $(0.4)$ & $(0.3)$ & $(0.4)$ & (1.6) & $(0.2)$ \\
\hline
\end{tabular}

* Mean (standard deviation) with sample size of 3.

$\uparrow$ Underscoring indicates no significant difference at $95 \%$ level of confidence.

\section{Discussion}

The DTA thermograms (Figure 1) of the dental impression waxes tested, except $\mathrm{F}$ and $\mathrm{J}$, are characteristic of hydrocarbon waxes such as paraffin and ceresin, in which the initial endothermic transition corresponds to a solid-solid phase transition and the large endothermic transition corresponds to melting. ${ }^{1}$ The broad melting peaks associated with $\mathrm{D}$ and $\mathrm{E}$ suggest mixtures of these hydrocarbon waxes, whereas the sharp melting peaks of $\mathrm{A}, \mathrm{B}, \mathrm{C}, \mathrm{G}, \mathrm{H}$, and I are characteristic of either of these waxes in high concentrations. Wax $\mathrm{F}$ has a thermogram characteristic of beeswax ${ }^{1}$ and is identified as pure beeswax by the manufacturcr on the pack-

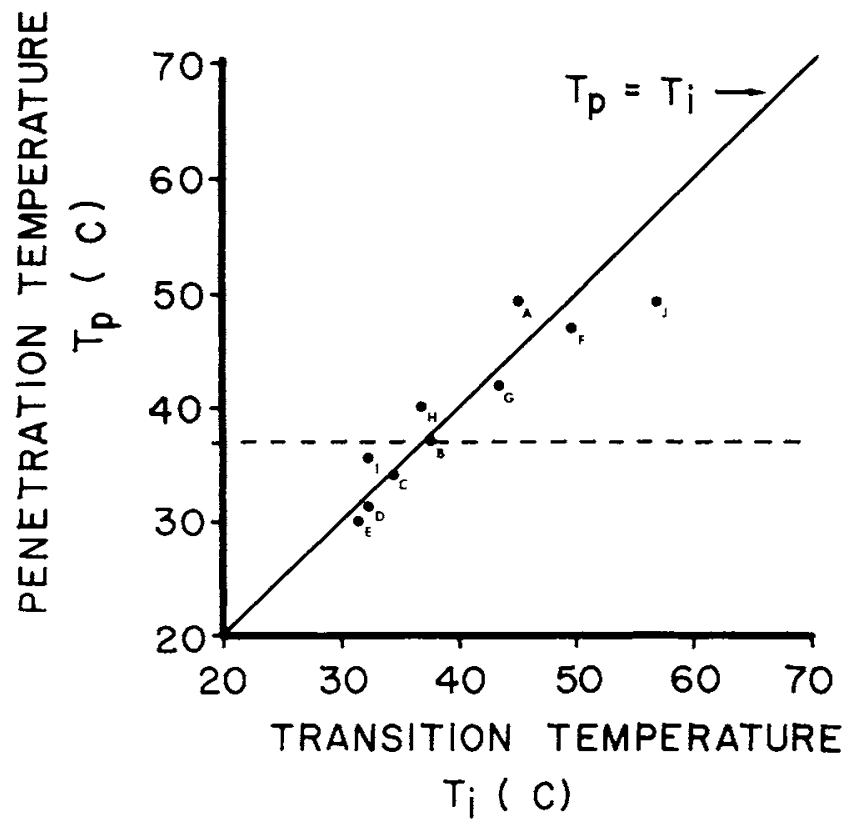

FIG 2. - Temperature $\left(\mathrm{T}_{\mathrm{H}}\right.$, corrected) at which $90 \%$ penetration occurred versus initial DTA transition temperature ( $T_{i}$, corrected). The solid line indicates a theoretical curve for which both temperatures are identical. The broken line indicates $\mathrm{T}_{p}=37 \mathrm{C}$. 
age. The initial transition $(56.6 \mathrm{C}$ ) of $\mathrm{J}$ is characteristic of melting of a hydrocarbon wax such as paraffin. The broad melting transition and the lack of an endothermic transition corresponding to a solid-solid phase change suggest the presence of additional components. The transition at $74.8 \mathrm{C}$ is characteristic of carnauba wax, a high melting ester wax. ${ }^{1}$

The penetration curves at the high stress level (Figure 1) of the impression waxes, except $\mathbf{F}$ and $J$, were related to the solid-solid phase transformations of the hydrocarbon components. The melting transition of the wax appears to have had little effect on penetration at $250 \mathrm{kPa}$. For wax $\mathrm{F}$, which is a mixture of hycirocarbon and ester waxes, penetration at the high stress is related to melting of the hydrocarbon component, whereas at the low stress penctration is influenced by the melting transition of the ester component. For J, penetration at both stress levels is related to the broad melting transition of the hydrocarbon component of the wax.

Clinically, waxes D, E, and I are used to make impressions of the soft oral tissues. For this application high flow at mouth temperature is desirable and was observed at both stress levels. Waxes A, B, and C are used to support $\mathrm{D}$ and had less flow at mouth temperature than D. Waxes F, G, H, and J are used clinically to make impressions of the occlusal surfaces of the teeth. During removal of the impression, low flow is desirable to minimize distortion. At 250 $\mathrm{kPa}$ the penetration of $\mathrm{F}, \mathrm{G}$, and $\mathrm{J}$ was between 2.5 and $8 \%$, but for $\mathrm{H}$ was $22 \%$. The relatively high flow of $\mathrm{H}$ may be justified because of its use as a functional bite wax.

\section{Conclusions}

Ten dental impression waxes were characterized by penetration and DTA. Among the waxes that were compounded from hydrocarbon waxes, penetration at $250 \mathrm{kPa}$ was correlated to the solid-solid phase transformation. Penetration at $250 \mathrm{kPa}$ of the waxes containing both hydrocarbon and ester components was determined by the melting transition of the hydrocarbon wax. Penetration at $37 \mathrm{G}$ ranged from 2.5 to $22 \%$ for bite waxes and was $100 \%$ for corrective waxes. Distortion of an impression wax may occur upon removal from the mouth.

\section{References}

1. Craig, R.G.; Powers, J.M.; and Peyton, F.A.: Differential Thermal Analysis of Commercial and Dental Waxes, J Dent Res 46: 1090-1097, 1967.

2. Powers, J.M., and Graig, R.G.: Penetration of Commercial and Dental Waxes, $J$ Dent Res 53:402-409, 1974.

3. Powers, J.M., and Craig, R.G.: Thermomechanical Analysis of Dental Waxes in the Penetration Mode, in Porter, R.S., and Johnson, J.F. (eds): Analytical Calorimetry, Volume 3, New York: Plenum Press, 1974, pp 349-362.

4. CRaig, R.G., and Peyton, F.A. (eds): Restorative Dental Materials, 5th Edition, St. Louis: C. V. Mosby Co., 1975, 495 pp.

5 American Dental Association: Guide to Dental Materials and Devices, 7th ed, Chicago, American Dental Association, 1974-1975, $297 \mathrm{pp}$.

6. University of Michigan, Statistical Research Laboratory: A Manual of Elementary Statistics Using MIDAS, Ann Arbor, Statistical Research Laboratory, 1975, 301 pp.

7. Guenther, W.C.: Analysis of Variance, Englewood Cliffs, N.J., Prentice-Hall, Inc., 1964, $141 \mathrm{pp}$. 